\title{
An investigation of the determinants of estate and retirement planning in intergenerational family businesses
}

\author{
S.P. van der Merwe* \\ Potchefstroom Business School, North-West University, \\ Private Bag X6001, Potchefstroom 2531, Republic of South Africa \\ Stephan.vandermerwe@nwu.ac.za
}

Received April 2009

\begin{abstract}
This study highlighted the importance of estate and retirement planning in small and medium-sized family businesses. Data from 504 questionnaires linked to 81 family businesses were collected and analysed. An Oblimin oblique rotation was performed on the principal components of the exploratory factor analysis. Five factors with eigenvalues greater than one, explaining $65.78 \%$ of the variance, were extracted. These five factors describing the theoretical dimensions of retirement planning, perceived fairness of the will, estate taxes, perceived liquidity of the business after succession and acquiring equity ownership were extracted. No practical significant differences could be found between the perceptions of male and female respondents as well as between family members involved in medium-sized or small businesses with regard to the five factors. Practical recommendations are suggested to ensure a smooth final transfer of the management and control of the business to the next generation family members.
\end{abstract}

*To whom all correspondence should be addressed.

\section{Introduction}

Family businesses make an important contribution to economic growth and wealth creation in the world (Basu, 2004:13, Morck \& Yeung, 2004:391; Astrachan \& Shanker, 2003:212; Ibrahim, Soufani \& Lam, 2001:245; Birley, Ng \& Godfrey, 1999:598). South Africa is no exception. It is estimated that $80 \%$ of businesses in South Africa could be classified as family businesses and these businesses comprise $60 \%$ of the companies listed on the Johannesburg Stock Exchange (Ackerman, 2001:325). Maas, Van der Merwe and Venter (2005:52) emphasised that, because of the important role family businesses perform in the South African economy, its survival is of the utmost importance. The sad news however, is that very few family businesses survive to the second generation and considerably less make it to the third (Bareither \& Reischl, 2003:21; Lea, 1991:13). A variety of maladies can lead to their downfall, but a large number of family businesses fail because of succession failure (Ibrahim \& Ellis, 2004:7; Kets de Vries, 1996:7), mainly as a result of inadequate succession planning (Bareither \& Reischl, 2003:21; Lansberg, 1999:37).

File and Prince (1996) find that inadequate estate planning is more often a cause of family business failure than is poor management succession planning. Venter, Boshoff and Maas (2003:6) points out that the critical importance of estate planning in the succession process is welldocumented in family business literature (e.g. Hume, 1999:28; Sturgill, 1998:60) especially in small and mediumsized businesses where the owner and manager are often the same person.
For the purpose of this study, a small and medium-sized family business is defined as a business that employs less than 200 full-time equivalents of paid employees, at least 51 percent of the business is owned by a single family, at least two family members are involved in the management or operational activities in the business and the transfer of leadership to next generation family members is anticipated (Ibrahim \& Ellis, 2004:5; National Small Business Act, 1996; National Small Business Amendment Act, 2004:2).

\section{Problem statement}

Although family businesses play a vital role in the world economy, this sector has received little attention in research, partly because of the difficulty in obtaining reliable data on these firms (Villalonga \& Amit, 2006:414). Various scholars highlighted, however, that family business research have recently been embraced within mainstream business research (Steier \& Ward, 2006; Klein, Astrachan \& Smyrnios, 2005:321; Chrisman, Chua \& Steier, 2003; Bird, Welsh, Astrachan \& Pistrui, 2002).

Brockhaus (1996:3) points out that relatively little research has been carried out in South Africa on family-run businesses. During the past decade, however, research on family businesses in South Africa gained more momentum (Van der Merwe, 2007; Van der Merwe \& Ellis, 2007; Venter \& Boshoff, 2006; Adendorff, Boshoff, Court \& Radloff, 2005; Venter, 2003a; Venter, 2003b; Van der Merwe 1998; amongst others), but more scientific-based research is urgently needed. 
The inadequate transfer of leadership and ownership from one generation to the next has been identified as one of the primary reasons for the lack of longevity among small and medium-sized family businesses (Venter \& Boshoff, 2007; Corbetta \& Montemerlo, 1998). Ryan (1995:13) confirms that estate and retirement planning are important in ensuring the future success of the family business. Thomas (2002:321), however, stressed that ownership succession have received less attention than management succession in the literature.

There is ample justification, against the barren background of scientific value-added research, as well as the importance of ownership succession to ensure the successful transfer of the business from the senior generation to the younger generation as highlighted in the literature, to pursue more earnest investigations into the dynamics of ownership succession in family businesses globally, in general, and specifically in the South African business environment.

\section{Objectives of the study}

The primary objective of this study was to explore the determinants of estate and retirement planning in small, micro and medium-sized family businesses in the South African context. In order to address the primary objective, the following secondary objectives were formulated:

- To obtain insight into the dynamics of estate and retirement planning in family businesses by means of a literature study.

- To identify the items that could assess the perceptions of family members regarding estate and retirement planning in family businesses.

- To validate the diagnostic questionnaire by means of statistical analysis.

- To examine the relationship (correlation) between the constructs, i.e. retirement planning, perceived fairness of the will, impact of estate taxes, perceived liquidity of the business after succession and acquiring equity ownership in the business.

- To examine the relationship between the constructs, i.e. retirement planning, perceived fairness of the will, impact of estate taxes, perceived liquidity of the business after succession and acquiring equity ownership in the business and the demographic variables gender and business size by means of t-tests and effect sizes.

- To suggest practical recommendation to improve the effectiveness of estate and retirement planning in small, micro and medium-sized family businesses.

\section{Literature review}

Ownership succession can be defined as a complete and irreversible legal succession from one owner to the next owner (Kenyon-Rouvinez \& Ward, 2005:59). Cohn (1992:24) adds that ownership succession is the process of deciding, communicating and implementing a plan with the intent to transfer ownership, i.e. transfer of shares or assets of the family business, to the next generation. The focus with ownership succession is on whom, thus family members, non-family members or a third party. Ownership succession also focuses on when and how the transfer will occur (Cohn, 1992:24).

Maas et al. (2005:80) refer to ownership succession as a life long process that enables the family to arrange, manage and secure its assets and liabilities. Evidently the outcome of the process is the protection, transition and development of the business and other assets to the benefit of the family without prejudicing any inactive family members. File and Prince (1996:172) stated that ownership planning is a crucial element in understanding family businesses due to the fact that most family business owners hold their principal assets within the business. For a family business ownership planning include continuity, personal financial security, equitable treatment of the next generation and tax savings (Aronoff, Astrachan \& Ward, 2002:184).

\section{Estate planning}

The importance of estate planning as a critical part of the succession process is well documented in family business literature (see for example Venter \& Boshoff, 2007:44; Bjuggren \& Sund, 2001; Hume, 1999; Sturgill, 1998).

Fishkind and Kautz (2002:3) defined estate planning as the process by which a person's asset base is assessed as well as the needs of the loved ones, and, with the assistance of a qualified estate planner, implement a plan for the purpose of passing on the wealth. Thus, estate planning refers to the ownership (asset) transitioning process (File \& Prince, 1996:172) and the estate plan assist a family business to make the transition from one generation to the next (Aronoff \& Ward, 2001:24).

Venter and Boshoff (2007:44) refer to a study undertaken by File and Prince (1996) among family businesses that failed, that demonstrated that inadequate estate planning was more often associated with family business failure than poor management succession planning. It is thus, according to Venter and Boshoff (2007:44), clear that a large volume of evidence in the literature supports the view that estate planning impacts positively on the success of the succession process. Venter et al. (2003:13) find that estate planning has a significant influence on the continued profitability of the business.

The goal of the estate plan is to pass wealth to one's loved ones in a manner that encourages harmony, personal growth and independence in the most tax efficient manner (Fishkind $\&$ Kautz, 2002:3). The will and testament of the decedent will have a major impact on the lives of the surviving loved ones (Fishkind \& Kautz, 2002:7). As a cornerstone to the estate plan, the last will and testament will help guide the distribution of the wealth that took the decedent a lifetime to accumulate (Fishkind \& Kautz, 2002:7). The estate plan should, however, be tailored to suit the unique needs of the specific family and should be carried out by capable fiduciaries. 
Disputes and grudges over inheritance provide a plentiful supply of family conflict and this is especially so when a business is involved (Leach \& Bogod, 1999:233). All too often when reviewing the last will and testament, the heirs can only shake their heads in disbelief when advised that their spouse or parent's last will and testament was 30 years old, and did not, in any way, shape, or from, or reflect their wishes (Fishkind \& Kautz, 2002:7).

\section{Impact of estate taxes}

In early generation family businesses, a key shareholder's death, in most instances the senior generation ownermanager may give rise to overwhelming estate tax demands (Astrachan \& Tutterow, 1996:313; De Visscher, Aronoff \& Ward, 1995:4). Often the estate has to be liquidated to pay estate taxes, or an unforeseen disaster can leave owners without the means, or ability, to complete their embryonic buy-out plan (Jaffe, 1991:222). This often serious liquidity problems experienced by families faced with inheritance taxes are usually shifted to the family business, as the family rarely has sufficient personal funds to cover taxes entirely (Neubauer \& Lank, 1998:193).

Passing down ownership of the family business to the next generation without incurring huge tax liabilities, requires careful and detailed planning (Leach \& Bogod, 1999:231). Venter et al. (2003:13) confirm that the economic consequences of estate taxes on family business activities may be significant. It is, therefore, of utmost importance that the impact of estate taxes is calculated and planned. A study by Morris, Williams, Allen and Avila (1997: 386) revealed that family business successions ran smoothly when family businesses engaged in planning for taxation and wealthtransfer purposes.

Planning in advance for retirement will enable family businesses to minimise inheritance tax and make sure that there is a smooth transition to the next generation of management (Thornton, 1998:69). Tax avoidance is a highlevel objective in estate and transition planning, but it shouldn't stand alone in any order of priority (Jonovic, 1997:140). Tax considerations should serve, instead, as touchstones in comparing competing planning options, rather than drivers of the planning process itself.

\section{Retirement planning}

Typically, family businesses have no mandatory retirement age, at least not one that applies to executives of the family (Lansberg, 1999:249). For the senior generation ownermanager, the freedom to set the pace of their departure is one of the benefits of owning a business. It allows them to customise the process of their retirement in such a way that is consistent with their health and individual preferences.

The mere fact that a senior member retires from the business does not mean he or she no longer has expenses. Potts, Schoen, Loeb and Hulme (2001:86) urge that ensuring financial stability is a critical issue when owner-managers consider withdrawing from the family business. In order to put together a sound plan for retirement, the family business owner-manager needs to know his/her financial needs after retirement (Voeller, Fairburn \& Thompson, 2002:28). Swart (2005a:74) stressed that once the senior generation ownermanager has developed a vision for their future they can begin planning to ensure they have the financial security to live their dream. Most retirees have not developed enough financial independence to sever their financial ties with the business (Aronoff \& Ward, 1993:36). Many make the mistake of simply staying on the payroll (Aronoff \& Ward, 1993:36).

\section{Ownership transfer to the younger generation family members}

Thomas (2000) find in a recent Australian study that the need to resolve family business ownership issues was seen as something that takes place between individuals and their accountants and lawyers. Attitudes to aspects of inheritance and the passing on of ownership were not forthcoming in the interviewee's responses about succession; they mainly focussed on provision for the senior generation in retirement and management succession issues, with a few direct references to share transfer arrangements. Ownership transfer was thus, according to the study, not addressed proactively.

These findings are consistent with those of Smyrnios, Romano and Tanewski (1997) that only 30\% of Australian family businesses have succession plans for future ownership and with Handler's view (1990) finding of a resistance to face the issue of timely ownership transfer. The author notes that in family businesses, the process of ownership transfer is often accomplished slowly or even avoided in order for the predecessor to maintain control. Larsson, Lindgren and Nyberg (2000) noted that benefits of stable ownership combined with a flexible approach to strategy for the long-term viability of the family-owned enterprise (also refer to Thomas, 2002:324).

\section{Perception of equality and fairness of the will}

An important aspect in estate planning pertains to the perception of equality and fairness of the will of the business owner (Robberts, 2006:57). According to Jaffe (1991:229), the confusion of fairness and equality causes problems in allocating family inheritance and when making decisions regarding ownership and control of the business. Parents are often of the opinion that children should inherit equally. However, equality for the family members can result in being unfair to some of the family members. It can even been demoralising and dangerous to the business. Leach and Bogod (1999:231) agree with Jaffe (1991:229) that fairness does not necessary mean equal. The family members who inherit the family business should deserve the inheritance (Robberts, 2006:57). Jaffe (1991:229) also rightfully remarked that passive owners have different needs. Because of different needs and perspectives, everyone will have his or her own ideas of what is fair.

As hard as the owner-manager may try to be fair to all the heirs, fairness differs in the eyes of the beholder, and conflict over inheritances is common, particularly when a business is involved. The principal cause of unhappiness is probably due to the assumption that fairness, by definition, 
means equal and when applied to a business, it fails to recognise the differing interests of those children who are active in the business and those who are not (Thornton, 1998:69).

\section{Perceived liquidity of the business after succession}

According to Libby, Libby and Short (2001:488) the word liquid, as in the context of how liquid a business is, means the ability of a business to meet its currently maturing debts. Aronoff and Ward (2002:25) defined liquidity as the term used for an investment or asset that can quickly be turned into cash. This definition is supported by Emens and Wolper (2000:46).

Liquidity needs in family businesses are caused by the capital requirements of the business (Neubauer \& Lank, 1998:191). Swart (2005a:75) emphasised that too few family business owners have an accurate idea of how much it will cost to settle their estate, or when the taxes and other expenses must be paid (Emens \& Wolper, 2000:46). De Visscher et al. (1995:4) stated that many family businesses failed because capital or liquidity problems prevent them from surviving generational, strategic or ownership transitions. Even though the estate tax laws contain special provisions allowing for delayed payment in some cases, it is vital to focus on liquidity needs (Emens \& Wolper, 2000:46).

Some of the expenses requiring cash from the estate's fiduciary include income taxes, probate and administration costs, payment of any maturing debts, funds to continue the operation of the family business and payment for mistakes while new management is learning the business (Swart, 2005a:75, 76; Emens \& Wolper, 2000:46). Senior generation owner-managers need thus to give thought to liquidity, that is, how business assets can be converted to cash to fulfil the desires of the individual owners who want to redeem their shares and how profits will be used (Swart, 2005b:106; Aronoff \& Ward, 2002:28).

\section{Research methodology}

\section{Development of the measuring instrument}

The literature study provided valuable insight into the identification of issues regarding ownership succession in family businesses and six latent constructs which could be used to measure the perceptions of family members regarding estate and retirement planning were identified. These are: i.e. estate planning (EP), impact of estate taxes (Tax), acquiring equity ownership in the business (Own), perceived fairness of the will (Fair), retirement planning (Ret) and perceived liquidity of the business after transfer (Liq). A comprehensive measuring instrument was designed to evaluate these constructs.

The measuring instrument was developed in three phases. These are: The items to measure each latent variable were formulated after a comprehensive review of the family business literature. As far as possible, instruments where used that have demonstrated acceptable validity and reliability in previous empirical studies (Venter, 2003a;
Sharma, 1997; File \& Prince, 1996). Where that was not possible, self-generated scales were used to measure the latent variables. The instrument was then tested at a single family business; subsequently the instrument was piloted at nine family businesses with 71 family members who completed the pilot questionnaires. The measuring instrument was then refined after each phase, followed by the drafting of an adapted version of the instrument.

The third version of the measuring instrument (used in this study) assessed the six latent variables with 32 statements on the basis of a 7-point Likert type scale ranging from Strongly Disagree (1) to Strongly Agree (7).

\section{The study population}

The target population of this study was small and mediumsized family businesses in South Africa. Numerous attempts were made to secure a database of family businesses in South Africa, but to no avail. Therefore, it was decided to use a convenience sample, by means of the snowball sampling technique, to identify the family businesses that participated in this study (Page \& Meyer, 2000:100). To generate a preliminary list of family businesses, well-known business people were contacted in various regions in South Africa. These business people then acted as informants and identified potential family businesses for inclusion in the sample. The latter then identified a further set of family businesses. These referrals were subsequently contacted telephonically to confirm that they adhere to the definition of small and medium-sized family businesses used in this study (Ibrahim \& Ellis, 2004:5; National Small Business Amendment Act, 2004:2; National Small Business Act, 1996) and to gauge their willingness to participate in the study. A list of 185 family businesses willing to participate in the study was compiled as a result of these efforts.

\section{Data collection}

The techniques to distribute and complete the questionnaires included: distribution of questionnaires via post, e-mail or facsimile, personal delivery of questionnaires, followed up by telephone calls, telephone interviews or structured interviews. Each questionnaire was sent with a covering letter that guaranteed the confidentiality of the responses, as well as a return-paid envelope in order to make it as easy as possible for respondents to take part in the research. A total of 504 usable questionnaires were returned from 81 intergenerational family businesses.

\section{Statistical analysis}

The data collected were statistically analysed, using Statistica (Statsoft, 2008) and SPSS (SPSS, 2008). Construct validity of the measuring scale was assessed by means of an exploratory factor analysis and by calculating Cronbach alpha coefficients. The relationship between the five extracted factors was examined by means of correlation analysis. Thereafter, the relationship between the demographic variables family employee gender and the size of the business; and the constructs was explored by means of t-tests and effect sizes (SPSS, 2008). 
To address the objectives of this study, the following propositions were formulated:

$\mathbf{P}^{1}$ : $\quad$ The measuring instrument has acceptable construct validity

$\mathbf{P}^{2}: \quad$ The measuring instrument has acceptable reliability

$\mathbf{P}^{3}: \quad$ There is a correlation (relationship) between the constructs, i.e. retirement planning, perceived fairness of the will, impact of estate taxes, perceived liquidity of the business after transfer and acquiring equity ownership in the business

$\mathbf{P}^{4}$ : There is a difference between the perception of male and female family employees with regard to the constructs, i.e. retirement planning, perceived fairness of the will, impact of estate taxes, perceived liquidity of the business after transfer and acquiring equity ownership in the business

$\mathbf{P}^{5}: \quad$ There is a difference between the perception of family members employed by small and mediumsized family businesses with regard to the constructs, i.e. retirement planning, perceived fairness of the will, impact of estate taxes, perceived liquidity of the business after transfer and acquiring equity ownership in the business

\section{Results and discussion}

\section{Demographic information}

The majority of the 504 participating respondents were under the age of 40 years $(58,13), 11,31 \%$ between the ages of 40 and 49, with $30,56 \%$ over the age of 50 years. Furthermore, an approximately equal distribution between male and female respondents was evident $(51,19 \%$ male, $48,81 \%$ female). A total of $17,28 \%$ of the 81 family businesses who participated in this study can be categorised as micro- and very small businesses in the South African context (10 employees and less) and 59,26\% small businesses (between 11 and 50 permanent employees). The rest $(23,56 \%)$ can be categorised as medium-sized businesses (between 51 and 200 employees).

\section{Construct validity of the measuring instrument}

To assess the discriminant validity of the 32 items measuring estate and retirement planning in family businesses, an exploratory factor analysis was conducted using the computer programme SPSS (SPSS, 2008). In this study, there was theoretical justification to believe that the factors measuring management succession planning would correlate with each other, therefore an Oblimin oblique rotation was performed on the principal components of the exploratory factor analysis, as suggested by Field
(2005:636). The correlation matrix for these five constructs indicates correlations of 0,059 to 0,475 between the constructs (Ellis \& Steyn, 2003:53), confirming that an oblique rotation should have been used (Field, 2005:636).

Kaiser's criterion was used to determine the number of factors to be extracted, namely to retain factors with eigenvalues greater than one (Field, 2005:735). All 32 items demonstrated sufficient discriminant validity by loading to a sufficient extent and, therefore, no item was deleted. The pattern matrix of the 32 items is provided in Table 1. Factor loadings greater than 0,35 were considered significant.

Five factors with eigen-values greater than one, explaining $65,78 \%$ of the variance before rotation, were extracted in the exploratory factor analysis. After rotation, these factors could be identified as the theoretical dimensions of retirement planning, perceived fairness of the will, impact of estate taxes, perceived liquidity of the business after transfer and acquiring equity ownership in the business. When factors are correlated, sums of squares of loadings cannot be added to obtain a percentage variance explained for each of the rotated factors as in the case of uncorrelated factors (SPSS, 2008). The Kaiser-Meyer-Olkin measure of sampling adequacy of 0,944 indicates that patterns of correlations are compact and that factor analysis should yield reliable factors (Field, 2005:640). Bartlett's test of sphericity yielded a p-value of smaller than 0,0001 indicating that correlation between variables are sufficient for factor analysis.

After rotation two of the items loaded onto more than one factor (values greater than 0,35). The item, EP2, loaded on both the factors impact of estate taxes and acquiring equity ownership in the business. The item, EP5, furthermore, loaded on both the factors impact of estate taxes and retirement planning. Rather than deleting the items, it was decided to classify it under the factor that yielded the highest factor loading. The classification of both items under the factor impact of estate taxes, also has the highest interpretation value and, furthermore, makes sense in practice.

Factor one, labelled retirement planning, comprised 10 items. All seven items that were used to measure the latent variable retirement planning (refer to Table 1) loaded onto factor one. Two items, EP7 and EP8 related to estate planning were also included in factor one, being regarded by respondents as being related to retirement planning. The item, Own2, used to measure the latent variable equity ownership, was also included in factor one, being regarded by respondents as also being related to factor one. 
Table 1: Pattern matrix of Oblimin rotated-principal component factor analysis ${ }^{(1)}$

\begin{tabular}{|c|c|c|c|c|c|}
\hline Item $^{(2)}$ & $\begin{array}{c}\text { Factor 1: }^{(3)} \\
\text { Retirement } \\
\text { planning }\end{array}$ & $\begin{array}{l}\text { Factor 2: Perceived } \\
\text { fairness }\end{array}$ & $\begin{array}{c}\text { Factor 3: Estate } \\
\text { taxes }\end{array}$ & $\begin{array}{c}\text { Facto 4: } \\
\text { Liquidity after } \\
\text { transfer }\end{array}$ & $\begin{array}{l}\text { Factor 5: Equity } \\
\text { ownership }\end{array}$ \\
\hline Ret4 & 0,833 & 0,033 & 0,118 & 0,150 & $-0,098$ \\
\hline Ret6 & 0,815 & $-0,112$ & $-0,114$ & $-0,022$ & 0,140 \\
\hline Ret5 & 0,798 & $-0,087$ & $-0,100$ & 0,069 & $-0,016$ \\
\hline Ret3 & $\mathbf{0 , 7 8 7}$ & 0,108 & 0,054 & 0,123 & 0,108 \\
\hline EP7 & 0,775 & 0,071 & $-0,065$ & $-0,226$ & $-0,021$ \\
\hline Ret1 & 0,764 & 0,031 & 0,064 & 0,131 & 0,009 \\
\hline Ret7 & 0,699 & 0,095 & $-0,102$ & 0,215 & $-0,054$ \\
\hline EP8 & 0,567 & $-0,033$ & $-0,268$ & $-0,154$ & 0,091 \\
\hline Own2 & 0,463 & 0,202 & 0,108 & $-0,155$ & 0,313 \\
\hline Ret2 & 0,438 & $-0,028$ & $-0,336$ & 0,021 & 0,234 \\
\hline Fair4 & $-0,042$ & 0,860 & 0,054 & 0,108 & 0,097 \\
\hline Fair3 & $-0,024$ & 0,851 & 0,006 & 0,122 & 0,008 \\
\hline Fair2 & 0,023 & 0,850 & 0,021 & 0,058 & 0,019 \\
\hline Fair1 & 0,054 & $\mathbf{0 , 8 0 1}$ & 0,060 & $-0,055$ & 0,095 \\
\hline Fair5 & $-0,092$ & 0,777 & $-0,039$ & 0,001 & 0,051 \\
\hline EP4 & 0,079 & 0,496 & $-0,295$ & $-0,272$ & $-0,058$ \\
\hline EP3 & 0,192 & 0,446 & $-0,271$ & $-0,272$ & $-0,117$ \\
\hline Tax5 & $-0,015$ & 0,171 & $-0,816$ & 0,019 & $-0,222$ \\
\hline Tax3 & 0,065 & 0,096 & $-0,797$ & $-0,087$ & $-0,093$ \\
\hline Tax1 & 0,005 & $-0,098$ & $-0,785$ & $-0,054$ & 0,051 \\
\hline Tax2 & 0,089 & $-0,074$ & $-0,771$ & 0,117 & 0,154 \\
\hline Tax4 & $-0,019$ & $-0,035$ & $-0,711$ & 0,193 & 0,254 \\
\hline EP2 & $-0,145$ & 0,144 & $-0,664$ & 0,097 & 0,357 \\
\hline Liq2 & 0,213 & 0,314 & $-0,521$ & $-0,088$ & $-0,175$ \\
\hline EP6 & 0,308 & 0,202 & $-0,473$ & 0,050 & 0,036 \\
\hline EP5 & 0,355 & 0,062 & $-0,419$ & $-0,002$ & 0,189 \\
\hline Liq3 & 0,335 & 0,077 & $-0,012$ & 0,609 & 0,076 \\
\hline Liq1 & 0,194 & 0,163 & $-0,284$ & 0,556 & 0,022 \\
\hline Liq2 & 0,322 & 0,322 & $-0,264$ & 0,445 & $-0,139$ \\
\hline Own1 & $-0,066$ & 0,173 & $-0,058$ & 0,146 & 0,693 \\
\hline Own3 & 0,286 & 0,061 & $-0,136$ & $-0,059$ & 0,519 \\
\hline EP1 & 0,257 & 0,299 & $-0,094$ & $-0,187$ & 0,471 \\
\hline Cronbach Alpha & 0,924 & 0,883 & 0,921 & 0,770 & 0,704 \\
\hline
\end{tabular}

(1) Loadings greater than 0.35 were considered significant

(2) The items included in the factor analysis are provided in Appendix 1

(3) The five extracted factors were labelled as follow:

Factor 1: Retirement planning (retirement planning)

Factor 2: Perceived fairness of the will (perceived fairness)

Factor 3: Impact of estate taxes (estate taxes)

Factor 4: Perceived liquidity of the business after transfer (liquidity after transfer)

Factor 5: Acquiring equity ownership in the business (equity ownership)

The second factor, labelled perceived fairness of the will, comprised seven items. All five items that were used to measure the latent variable, perceived fairness of the will (Table 1), loaded onto factor two as expected. Two estate planning items (Table 1: EP3 and EP4) also loaded onto factor two. The respondents thus regarded these items as additional measures of the variable perceived fairness of the will.

With regard to the third factor, labelled impact of estate taxes, all five items that were used to measure the latent variable, impact of estate taxes, loaded onto this factor. Three estate planning items, EP2, EP5 and EP6, also loaded onto factor three. The item, Liq2, categorised to measure the latent variable perceived liquidity of the business after succession, also loaded onto factor three. These four items were thus regarded by respondents as additional impact of estate taxes measures.

Three of the four items used to measure the latent variable perceived liquidity of the business after succession (Table 1: items Liq1, Liq2 and Liq3), loaded onto factor four, as expected. Factor 4 was labelled perceived liquidity of the business after succession.

Two of the three items (Table 1: Own1 and Own3) used to measure the latent variable acquiring equity ownership in the business, loaded onto factor five, also labelled acquiring equity ownership in the business. One estate planning item (Table 1: EP1), also loaded onto factor five, being regarded by respondents as related to acquiring equity ownership in the business. 
From the factor loadings it is clear that all eight items used to measure the latent variable, estate planning (refer to Appendix 1), were incorporated into other factors (Table 1). The wording of the statements (items) measuring the six latent variables are provided in Appendix 1.

The exploratory factor analysis, together with the interpretability of the factors, provides some evidence of construct validity, indicating that Proposition $1\left(\mathrm{P}^{1}\right)$ can be accepted.

\section{Reliability of the measuring instrument}

In order to assess the internal consistency between the items of the measuring instrument, Cronbach alpha coefficients were calculated (Page \& Meyer 2000:292). The Cronbach alpha coefficient is based on the average correlation of variables within a construct (SAS Institute, 2005:295). The greater the Cronbach alpha coefficient is, the more reliable the scale. Nunnally and Bernstein (1994:265) suggest that for acceptable reliability the Cronbach alpha coefficient should be greater than 0.7 .

All 504 participants' responses were used to determine the reliability of the extracted factors (refer to Table 1). The results indicate that the measuring instrument used in this study to measure management succession planning, has acceptable reliability, with no factors with a Cronbach Alpha value below the customary cut-off value of 0.70 suggested for internal consistency (Nunnally \& Bernstein, 1994:265). Proposition $2\left(\mathrm{P}^{2}\right)$ can thus be accepted.

\section{Relationship between the constructs}

To investigate the relationship between the five constructs, namely retirement planning, perceived fairness of the will, impact of estate taxes, perceived liquidity of the business after succession and acquiring equity ownership in the business, the Pearson correlation coefficients $(r)$ were calculated and are presented in Table 2 (refer to Field, 2005: 111). Factor scores for each participant were computed as the average of all items contributing to the relevant factor. This means that missing values for an individual were automatically replaced by the average of the other responses contributing to the relevant factor for the specific individual. The scores of family members belonging to a specific family can be considered to be dependent on that family's situation. As independence of data is a critical assumption of correlation analysis, the average counts for each of the 81 families were taken as data points in the correlation analysis.

In order to determine whether the effect of the relationship between two constructs is important or meaningful, the size of the effect should be measured. Effect sizes are useful because they provide an objective measure of the importance of an effect (Field, 2005:32). A correlation coefficient of 0 means there is no visible relationship, and a value of 1 means that there is a perfect relationship. Cohen (1992:155-159) gave the following widely accepted guidelines about the interpretation of effects:

- $r=0,10$ (small effect): in this case, the effect explains $1 \%$ of the variance

- $\quad r=0,30$ (medium effect): the effect accounts for $9 \%$ of the variance

- $\quad r=0,50$ (large effect): the effect accounts for $25 \%$ of the variance (refer to Field, 2005:32; Cohen, 1992:155159)

Table 2: Results of the Pearson correlation coefficients ( $r$ ) between constructs

\begin{tabular}{|c|c|c|c|c|c|}
\hline Variable & $\begin{array}{c}\text { Retirement } \\
\text { planning }\end{array}$ & $\begin{array}{c}\text { Perceived } \\
\text { fairness }\end{array}$ & Estate taxes & $\begin{array}{c}\text { Perceived } \\
\text { liquidity }\end{array}$ & Equity ownership \\
\hline Retirement planning & 1,00 & $0,461 * *$ & $0,669 * *$ & $0,660 * *$ & $0,570 * *$ \\
\hline Perceived fairness & $0,461 * *$ & 1,00 & $0,627 * *$ & $0,499 * *$ & $0,565 * *$ \\
\hline Estate taxes & $0,669 * *$ & $0,627 * *$ & 1,00 & $0,597 * *$ & $0,605 * *$ \\
\hline Perceived liquidity & $0,660 * *$ & $0,499 * *$ & $0,597 * *$ & 1,00 & $0,491 * *$ \\
\hline Equity ownership & $0,570 * *$ & $0,565 * *$ & $0,605 * *$ & $0,491 * *$ & 1,00 \\
\hline
\end{tabular}

** Correlations significant at the $\mathrm{p}=0,01$ level (2-tailed)

The results in Table 2 indicate that there are statistical significant $(p<0,01)$ correlations between all the construct combinations. Furthermore, practical significant (large effect: $r>0,500)$ correlations between all the construct combinations except for the correlation between the constructs retirement planning and perceived fairness of the will (medium effect: $r=0,461$ ) and between perceived fairness of the will and perceived liquidity of the business after succession were calculated (medium effect: $r=$ 0,499). Based on Cohen's guidelines (Cohen, 1992:155159), Proposition $3\left(\mathrm{P}^{3}\right)$ can thus be accepted.
Comparing the mean differences between constructs for demographic variables

An advantage of drawing a random sample is that it enables one to study the properties of a population with the time and money available (Ellis \& Steyn, 2003:51). In such cases the statistical significance tests (e.g. t-tests) are used to show that the result of the difference between two means, are significant. The authors further that the $p$-value is a criterion of this, giving the probability that the obtained value or larger could be obtained under the assumption that the null hypothesis (e.g. no difference between the means) is true. A small $p$-value (e.g. smaller than 0,05 ) is considered as 
sufficient evidence that the result is statistical significant. Statistical significance, however, does not necessarily imply that the result is important in practice as these tests have the tendency to yield small p-values (indicating significance) as the size of the data set increase (Ellis \& Steyn, 2003:51).

Data obtained from convenience sampling are, according to Steyn and Ellis (2003:51), often erroneously analysed as if it were obtained by random sampling. These data should be considered as a small population for which statistical inference and $p$-values are not relevant. Statistical inference draws conclusions about the population from which a random sample was drawn, using the descriptive measures that have been calculated. Instead of only reporting descriptive statistics, effect sizes can be determined. The effect size is independent of sample size and is a measure of practical significance (Ellis \& Steyn, 2003:51). Although the results of the t-test will be discussed, the findings of this study resulting of a convenience sample method will be based on the effect sizes ( $d$-values).

The differences in the means between the extracted factors, namely retirement planning, perceived fairness of the will, impact of estate taxes, perceived liquidity of the business after succession and acquiring equity ownership, (see Table 2), for the demographic variables gender of the participating family members were examined by paired t-tests and effect sizes ( $d$-values) because the responses of members of the same family can be considered to be dependent. The analysis was performed on a family level, where the average scores for each of the 81 families were taken as data points. The difference between the means of small and medium-sized businesses regarding the constructs will however be examined by independent $t$-tests and effect sizes.

These effect sizes $(d)$ will be interpreted, according to Cohen's guidelines, as follows: small effect $(d=0,2)$, medium effect $(d=0,5)$ and large effect $(d=0,8)$. Results with medium effects can be regarded as visible effects and with $d \geq 0,8$ as practically significant, since it is the result of a difference having a large effect (Field, 2005:32; Ellis \& Steyn, 2003:51-53; Thompson, 2001:80-93; Cohen, 1992:155-159).

Table 3 shows the relationships between the five constructs and the demographical variables gender, generation and business size respectively, with the mean $(\bar{X})$, standard deviation (s), t-tests ( $p$-value) and effect sizes ( $d$-value).

Table 3: Results of the differences in means between the constructs for the demographic variables gender and business size

\begin{tabular}{|c|c|c|c|c|c|c|c|c|}
\hline \multicolumn{9}{|c|}{ Gender } \\
\hline \multirow[t]{2}{*}{ Construct } & \multicolumn{3}{|c|}{ Male } & \multicolumn{3}{|c|}{ Female } & \multicolumn{2}{|c|}{ Comparison } \\
\hline & $n$ & $\overline{\bar{X}}$ & $S$ & $n$ & $\overline{\bar{X}}$ & $s$ & $p$ & $d$ \\
\hline Retirement planning & & 4,47 & 1,20 & & 4,37 & 1,14 & 0,347 & 0,11 \\
\hline Perceived fairness & & 5,11 & 0,86 & & 4,94 & 0,96 & 0,047 & 0,22 \\
\hline Estate taxes & & 4,31 & 0,95 & & 4,07 & 1,36 & 0,158 & 0,19 \\
\hline Perceived liquidity & & 5,20 & 0,84 & & 4,85 & 1,31 & 0,011 & 0,35 \\
\hline Equity ownership & & 4,08 & 1,22 & & 4,17 & 1,33 & 0,418 & 0,09 \\
\hline \multicolumn{9}{|c|}{ Business size } \\
\hline \multirow[t]{2}{*}{ Construct } & \multicolumn{3}{|c|}{ Micro \& Small } & \multicolumn{3}{|c|}{ Medium-sized } & \multicolumn{2}{|c|}{ Comparison } \\
\hline & $n$ & $\bar{x}$ & $s$ & $n$ & $\overline{\bar{X}}$ & $s$ & $p$ & $D$ \\
\hline Retirement planning & 62 & 4,32 & 1,07 & 19 & 4,66 & 0,99 & 0,225 & 0,31 \\
\hline Perceived fairness & 62 & 5,00 & 0,83 & 19 & 5,09 & 0,84 & 0,674 & 0,11 \\
\hline Estate taxes & 62 & 4,29 & 1,05 & 19 & 4,81 & 1,09 & 0,063 & 0,48 \\
\hline Perceived liquidity & 62 & 5,00 & 0,99 & 19 & 5,78 & 0,68 & 0,002 & 0,79 \\
\hline Equity ownership & 62 & 4,03 & 1,09 & 19 & 4,30 & 1,27 & 0,371 & 0,21 \\
\hline
\end{tabular}

The results indicated a statistical significant difference $(p<$ 0,05 ) in the mean values between the perceptions of male and females with regard to the constructs perceived fairness of the will $(p=0,047)$ and perceived liquidity of business after succession $(p=0,011)$. Although male participants rated the two constructs more positive than their female counterparts, the differences were not practical significant and only a small effect $(d=0,22$ and $d=0,35$ respectively) could be determined. The results indicate that, although the average scores for male family employees are higher than those for female family employees, it could not be regarded as a practically significant difference between the perceptions of male and female family employees regarding perceived fairness of the will and perceived liquidity of the business after succession. Based on Cohen's guidelines (Cohen, 1992:155-159), proposition $4\left(\mathrm{P}^{4}\right)$ can thus not be accepted.

Family members employed by medium-sized family businesses rated only one construct, perceived liquidity of the business after succession ( $p=0,002 ; d=0,79$ ), statistically and practically significant more positive than family members employed by small family businesses. It is thus clear that, although the average scores for family members employed by medium-sized family businesses are higher than those for small family businesses, it could not be regarded as a practically significant difference between the perceptions of family members employed by medium or small family businesses regarding the other four constructs measuring ownership succession in the participating family 
businesses. Based on Cohen's guidelines (Cohen, 1992:155159), and due to the fact that only one out of five constructs yielded practical significant differences in the mean values, proposition $5\left(\mathrm{P}^{5}\right)$ can thus not be accepted.

\section{Conclusions}

This study confirms the important role that estate and retirement planning play to successfully transfer the management and control of the family business to the next generation family members. Successful ownership succession can ensure the continuity and longevity of the family business (Venter \& Boshoff, 2007; File \& Prince, 1996).

This study reports some evidence of construct validity and reliability of a questionnaire to measure the determinants of estate and retirement planning small and medium-sized family businesses in South Africa. Five factors describing the theoretical dimensions of retirement planning, perceived fairness of the will, impact of estate taxes, perceived liquidity of the business after succession and acquiring equity ownership in the business, (see Table 1), were extracted. It is recommended that more advanced statistical procedures for scale validation, such as structural equation modelling, be utilised in further development of the measuring scale.

Statistical significant bivariate correlations of 0,461 to 0,669 were calculated between the constructs. There was, for instance, a strong positive correlation between the perceptions of family employees regarding retirement planning and estate taxes $(r=0,669)$ and perceived liquidity of the business after succession $(r=0,660)$ respectively. This study confirms the findings of other scholars such as Venter et al. (2003:44); Fishkind and Kautz (2002:7); Thornton (1998:69) and Jaffe (1991:222); amongst others, that highlighted the importance of retirement planning to minimise estate taxes and ensure the ability of the business to honour the liquidity needs of the business after succession in order not the put unnecessary risks on the continuity of the business as a family business after ownership succession.

The direction of causality and the influence of other variables on a specific bivariate correlation could not be determined. Care should, therefore, be taken when interpreting the correlation coefficients (Field, 2005: 128). Further research on these constructs is recommended to gain more insight into the causality of the constructs.

This study provides evidence that family members involved in medium-sized family businesses tend to be visible (medium effect) more positive to minimise the impact of estate taxes, and practically significant more positive about the perceived liquidity of the business after succession, in direct comparison with the family members involved in small businesses. This makes sense in practice because bigger businesses should have more capacity - finances and competences - in order to do estate and retirement planning and to absorb the impact of estate taxes and ensuring sufficient liquidity of the business after succession. No evidence could, however, be found in the family business literature to confirm this finding.

Although $\mathrm{P}^{4}$ and $\mathrm{P}^{5}$, based on Cohen's guidelines, cannot be accepted in this study (Cohen, 1992:155-159), it is important to take note of Thompson's argument (Thompson, 2001:80-93) not to use Cohen's guidelines in an overly rigid manner to interpreted the differences in means between variables. More empirical research is, therefore, needed to further examine these differences and to establish norms for future interpretation.

\section{Limitations and suggestions for further research}

The study attempted to make a contribution to the body of knowledge on the determinants of estate and retirement planning in small to medium-sized family businesses. This study, however, only assessed some of the determinants and can be regarded as an exploratory study. More comprehensive research is still needed to clarify all the underlying dimensions of ownership succession in family businesses to enhance our understanding of these issues.

Although family businesses from all provinces in South Africa took part in this study, due to the convenience sampling technique, this cannot be considered to be representative of all small and medium-sized family businesses in South Africa. Care should therefore be exercised in the interpretation and utilisation of the results, and the findings of the study cannot be generalised. In other words, the typical family business could be underrepresented in the sample.

In this study the exploratory factor analysis provides some evidence of construct validity, but further research is needed before the measuring scale can be utilised to diagnose these issues in small and medium-sized family businesses. It is recommended that more advanced statistical procedures for scale validation, such as structural equation modelling, should be utilised in further development of the measuring instrument. Supplementary research on the use of the measuring scale is also necessary to refine its norms.

Based on the fact that published evidence of a quantitative nature on ownership succession in small and medium-sized family businesses both nationally and internationally is lacking, the findings of this study presents challenges for further research.

A limitation is that this study relied completely on the respondents' perceptions. To close the gap between perception and reality, future research could be designed to collect field data on the determinants and realities of retirement and estate planning in practice. In-depth interviews with those involved in the transfer of the ownership to the next generation family members as well as the emotions attached to retirement planning could further contribute to the understanding of the dynamics and underlying processes of the transfer of the management and control of the family business to the next generation family members (refer to Venter \& Boshoff, 2007: 52). 


\section{Management implications}

Family members have negative connotations associated with estate planning (Leach \& Bogod, 1999:223). Venter et al. (2003:13) emphasised that it is predomately the responsibility of the senior generation owner-manager to ensure that the family business is financially secure after his retirement from the business.

Family businesses have unique capital needs including, for instance, buying out uninterested heirs (Swart, 2005b; Aronoff \& Ward, 2002:28). It is therefore important that the estate be planned timorously so as to maximise the benefit that the family could enjoy from it. The more dynamically the process is managed, the more the negative aspects will be minimised, and therefore, the greater the continued profitability of the business will be (Venter \& Boshoff, 2007:44; Venter et al., 2003:13).

It is suggested that the retirement of the senior generation owner-manager be planned for independently from the assets of the family business (Aronoff \& Ward, 1993). The senior generation should, if possible, secure a source of income separate from the business to be financially secure after retirement. If the senior generation family members are after retirement still dependent on the profits of the family business, the profitability and the continuity of the business could be affected if the process is not managed correctly (File \& Prince, 1996).

Retirement and estate planning is emotional issues. Therefore, thoughts and feelings about ownership succession need to be discussed through honest and open communication. Family members should become comfortable sharing ideas and different perspectives regarding retirement and estate planning. It is recommended that family businesses discuss ownership succession at an official family forum meeting. The family forum comprises all the adult family members, including inactive offspring and children-in-law. It is a good forum for expression of thoughts and feelings about ownership succession. When family members feel included and can voice their complaints, it is often possible to resolve problems and challenges collaboratively.

A financial advisor can assist the family in the succession process when estate planning is discussed and to mentor the ownership succession transfer from the senior to the younger generation. This includes aspects such as shareholding and equity and fair estate planning. Tax implications of the last will should also be discussed. Estate planning is critical to ensure the successful transfer of the ownership of the family farm to the younger generation family members.

The economic consequences of estate taxes on family businesses may be significant (Venter et al., 2003:13). It is thus important that family businesses start from an early stage to plan for the retirement of the senior generation family members and ownership transfer of the family

\section{References}

Ackerman, R. 2001. Hearing grasshoppers jump: The story of Raymond Ackerman as told to Denise Prichard. Claremont: David Philip.

Adendorff, C., Boshoff, C., Court, P. \& Radloff, S. 2005. 'The impact of planning on good governance practices in South African Greek family businesses', Management Dynamics, 14(4):34-46.

Aronoff, C.E. \& Ward, J.L. 1993. Family business compensation. Marietta, GA: Family Enterprise Publishers.

Aronoff, C.E. \& Ward, J.L. 2001. Family business values: how to assure a legacy of continuity and success. Marietta, GA: Family Enterprise Publishers.

Aronoff, C.E. \& Ward, J.L. 2002. Family business ownership: How to be an effective shareholder. Marietta, GA: Family Enterprise Publishers.

Aronoff, C.E., Astrachan, J.H. \& Ward, J.L. 2002. Family business sourcebook. $3^{\text {rd }}$ Edition. Marietta, GA: Family Enterprise Publishers.

Astrachan, J.H. \& Shanker, M.C. 2003. 'Family businesses' contribution to the U.S. economy: A closer look', Family Business Review, 16(3):211-219.

Astrachan, J.H. \& Tutterow, R. 1996. 'The effect of estate taxes on family business: survey results', Family Business Review, 9(3):303-314.

Bareither, K. \& Reischl, T. 2003. Planning a family \& business legacy. Avila Beach: FBR Publishing.

Basu, A. 2004. 'Entrepreneurial aspirations among family business owners: an analysis of ethnic business owners in the UK', International Journal of Entrepreneurial Behaviour \& Research, 10(1/2):12-33.

Bird, B., Welsh, H., Astrachan, J.H. \& Pistrui, D. 2002. 'Family business research: The evolution of an academic field, Family Business Review', 15(4):337-350.

Birley, S., Ng, D. \& Godfrey, A. 1999. 'The family and the business', Long Range Planning, 32(6):598-608.

Bjuggren, P. \& Sund, L. 2001. 'Strategic decision making in intergenerational successions of small- and medium-sized family-owned businesses', Family Business Review, 14(1):11-23.

Brockhaus, R.H., Sr. 1996. 'Family business in SouthernAfrica: An old new frontier'. Paper presented at the Ninth Annual Conference of the International Council for Small Business in Southern Africa, Nelspruit, May.

Chrisman, J.J., Chua, J.H. \& Steier, L.P. 2003. 'An introduction to theories of family business', Journal of Business Venturing', 18(4):441-448. 
Cohen, J. 1992. 'A power primer', Psychological Bulletin, 112(1): 155-159.

Cohn, M. 1992. Passing the torch: succession, retirement, \& estate planning in family-owned businesses. $2^{\text {nd }}$ Edition. New York, NY: McGraw-Hill.

Corbetta, G. \& Montemerlo, D. 1998. 'Managing succession in Italian small and medium-sized family businesses', The Family Business Network Newsletter, 20:8-10, May.

De Visscher, F.M., Aronoff, C.E. \& Ward, J.L. 1995. Financial transitions: managing capital and liquidity in family businesses. Marietta, GA: Business Owners Resources.

Ellis, S.M. \& Steyn, H.S. 2003. 'Practical significance (effect sizes) versus or in combination with statistical significance (p-values)', Management Dynamics, 12(4):5153.

Emens, J.R. \& Wolper, B.E. 2000. Family business basics: the guide to the family business financial success. New Albany, OH: AASF Publications.

Field, A. 2005. Discovering statistics using SPSS. London: Sage.

File, K.M. \& Prince, R.A. 1996. 'Attributions for family business failure', Family Business Review, 9(2):171-184.

Fishkind, R.J. \& Kautz, R.C. 2002. Estate \& business succession planning: A legal guide to wealth transfer. $2^{\text {nd }}$ Edition. New York. NY: Wiley.

Handler, W.C. 1990. 'Succession in family firms: A mutual role adjustment between entrepreneur and next-generation family members', Entrepreneurship Theory and Practice, 15(1):37-51.

Hume, S.A. 1999. 'An assessment of risk of family business failure'. Unpublished doctoral thesis, Antioch University, New Hampshire.

Ibrahim, A.B. \& Ellis, W.H. 2004. Family business management: Concepts and practice. $2^{\text {nd }}$ Edition. Dubuque, IA: Kendall/Hunt.

Ibrahim, A.B., Soufani, K \& Lam, J. 2001. 'A study of succession in a family firm', Family Business Review, 14(3):245-258.

Jaffe, D.T. 1991. Working with the ones you love: Strategies for a successful family business. Berkeley, CA: Conari Press.

Jonovic, D.J. 1997. The ultimate legacy: How owners of family and closely held businesses can achieve their real purpose. Cleveland, $\mathrm{OH}$ : Jamieson.

Kenyon-Rouvinez, D. \& Ward, J.L. 2005. Family business: key issues. New York, NY: Palgrave MacMillan.
Kets De Vries, M.F.R. 1996. Family business: Human dilemmas in the family firm. London: International Thomson Business Press.

Klein, S.B., Astrachan, J.H. \& Smyrnios, K.X. 2005. 'The F-PEC scale of family influence: Construction, validation, and further implication for theory', Entrepreneurship Theory and Practice, 29(3):321-339.

Lansberg, I. 1999. Succeeding generations: Realizing the dream of families in business. Boston, MA: Harvard Business School Press.

Larsson, M., Lindgren, H. \& Nyberg, D. 2000. 'Entrepreneurship, active ownership \& succession strategies: The long-term viability of the Swedish Bonnier and Wallenberg family business groups'. In Proceedings of the FBN Annual Conference, London, October, p.p.177-196.

Lea, J.W. 1991. Keeping it in the family: Successful succession of the family business. New York, NY: Wiley.

Leach, P. \& Bogod, T. 1999. Guide to family businesses. $3^{\text {rd }}$ Edition. London: Kogan Page.

Libby, R., Libby, P.A. \& Short, D.G. 2001. Financial accounting. $3^{\text {rd }}$ Edition. New York, NY: McGraw-Hill.

Maas, G.J.P., Van der Merwe, S.P. \& Venter, E. 2005. Family businesses in South Africa: A practical governance guide. Stellenberg: GEB Consultants.

Morck, R. \& Yeung, B. 2004. 'Family control and the rent seeking society', Entrepreneurship Theory and Practice, 28(4):391-409.

Morris, M.H., Williams, K.W., Allen, J.A. \& Avila, R.A. 1997. 'Correlates of success in family business successions', Journal of Business Venturing, 12:385-401.

National Small Business Act see South Africa.

National Small Business Amendment Act see South Africa.

Neubauer, F. \& Lank, A.G. 1998. The family business: Its governance for sustainability. Hampshire: MacMillan.

Nunnally, J. \& Bernstein, I.H. 1994. Psychometric theory. $3^{\text {rd }}$ Edition. New York, NY: McGraw-Hill.

Page, C. \& Meyer, D. 2000. Applied research design for business and management. Roseville: McGraw-Hill.

Potts, T.L., Schoen, J.E., Loeb, M.E., \& Hulme, F.S. 2001. 'Effective retirement for family business owner-managers: perspective of financial planner, Part 2', Journal of Financial planning, July.

Robberts, J. 2006. 'Evaluation of the unique challenges facing family businesses in South Africa'. Unpublished MBA dissertation, North-West University, Potchefstroom, South Africa. 
Ryan, C. 1995. 'Are family businesses better', Productivity South Africa, March/April:11-13.

SAS Institute Inc. 2005. SAS Institute Inc., SAS OnlineDoc®, Version 9.1. Cary, NC: SAS Institute.

Sharma, P. 1997. 'Determinants of the satisfaction of the primary stakeholders with the succession process in family firms'. Unpublished doctoral thesis, University of Calgary, Canada.

Smyrnios, K., Romano, C. \& Tanewski, G. 1997. The Australian family and private business survey. Melbourne: The National Mutual Family Business Research Unit, Monash University.

South Africa. 1996. 'National Small Business Act (Act 102 of 1996)', Government Gazette, 377(17612).

South Africa. 2004. 'National Small Business Amendment Act (Act 29 of 2004)', Government Gazette, 474(27101).

SPSS Inc. 2008 SPSS ${ }^{\circledR} 16.0$ for Windows, Release 16.0.0, Copyright $($ by SPSS Inc. Chicago, IL: SPSS.

Statsoft, Inc. 2008. Statistica (Data Analysis Software System). Vers. 7.1. URL:www.statsoft.com.

Steier, L.P. \& Ward, J.L. 2006. 'If theories of family enterprise really do matter, so does change in management education', Entrepreneurship Theory and Practice, 30(6):887-895.

Sturgill, T.C. 1998. 'The states, too, demand their pound of flesh', Family Business, 9(3):60-63.

Swart, H.C. 2005a. 'Evaluation of the factors that ensures long-term sustainability of family businesses'. Unpublished MBA dissertation, North-West University, Potchefstroom, South Africa.

Swart, P.J. 2005b. 'Unique challenges facing family businesses'. Unpublished MBA dissertation, North-West University, Potchefstroom, South Africa.

Thomas, J. 2000. 'The exercise of leadership in family business: perceptions of managers family and non-family in the Australian small to medium-sized enterprise sector'. Unpublished doctoral dissertation. University of South Australia.

Thomas, J. 2002. 'Freeing the shackles of family business ownership', Family Business Review, 15(4):321-336.
Thompson, B. 2001. 'Significance, effect sizes, stepwise methods, and other issues: Strong arguments move the field', Journal of Experimental Education, 70:80-93.

Thornton, G. 1998. Family businesses: How directors can manage key issues in a family firm. London: Director Publications.

Van der Merwe, S.P. 1998. 'Formal planning in family businesses in the Vaal Triangle'. Unpublished doctoral thesis, North-West University, Potchefstroom, South Africa.

Van der Merwe, S.P. 2007. 'Evaluation of the factors that ensure long-term sustainability of family farms', South African Journal of Agricultural Extension, 36:1-27.

Van der Merwe, S.P. \& Ellis, S.M. 2007. 'An exploratory study of some of the determinants of harmonious family relationships in small and medium-sized family businesses', Management Dynamics, 16(4):24-35.

Venter, E. 2003a. The succession process in small and medium-sized family businesses in South Africa. Unpublished doctoral thesis, University of Port Elizabeth, Port Elizabeth, South Africa.

Venter, W.P. 2003b. 'The role of familiness in the performance of family business groups'. Unpublished M. Phil dissertation, Rand Afrikaans University, Johannesburg, South Africa.

Venter, E. \& Boshoff, C. 2006. 'The influence of familyrelated factors on the succession process in small and medium-sized family businesses', South African Journal of Management and Economic Sciences, 9(1):17-32.

Venter, E. \& Boshoff, C. 2007. 'The influence of organisation-related factors on the succession process in small and medium-sized family businesses', Management Dynamics, 16(1):42-55.

Venter, E., Boshoff, C. \& Maas, G. 2003. 'The influence of organisational factors on successful succession in family business', Management Dynamics, 12(4):2-17.

Villalonga, B. \& Amit, R. 2006. 'How do family ownership, control and management affect firm value?' Journal of Financial Economics', 80(2):385-417.

Voeller, M., Fairburn, L. \& Thompson, W. 2002. Exit right: A guided tour of succession planning for families-inbusiness-together. $2^{\text {nd }}$ Edition. Toronto: Summit Run. 


\section{APPENDIX 1}

\begin{tabular}{|c|c|}
\hline Item & atement \\
\hline EP1 & $\begin{array}{l}\text { ritten decisions exist about the distribution of the family assets and ownership to the younger generation after } \\
\text { tirement of the senior generation family members }\end{array}$ \\
\hline EP2 & he goals of the estate plan are known to the family \\
\hline EP3 & he estate plan addresses future claims against the estate (e.g. previous marriages, minor children) \\
\hline EP4 & he senior generation family members have signed wills which were reviewed and updated during the past two years \\
\hline EP5 & he estate plan addresses the implications of the current and the heir's future form of enterprise \\
\hline EP6 & he senior generation family members have written estate plans that meet the unique needs of the family business \\
\hline EP7 & he estate plan provides in case of disability of the senior generation family members \\
\hline EP8 & te plan for threats such as divorce, matrimonial property system and insolvency \\
\hline Tax1 & $\begin{array}{l}\text { The capital gains tax to be paid by the family business when senior generation family members pass away was } \\
\text { determined }\end{array}$ \\
\hline Tax2 & $\begin{array}{l}\text { The family is informed about and is prepared for the impact of capital gains tax on the family business when senior } \\
\text { generation family members pass away }\end{array}$ \\
\hline Tax3 & The estate tax to be paid by the family business when senior generation family members pass away was determined \\
\hline Tax4 & $\begin{array}{l}\text { ly is informed about and is prepared for the financial impact that estate tax may have on the family business } \\
\text { ior generation family members pass away }\end{array}$ \\
\hline Tax5 & irements to minimise estate tax \\
\hline Own1 & $\begin{array}{l}\text { y which clearly stating who may own equity (ownership capital, shares, members' interest) in the family } \\
\text {, exists }\end{array}$ \\
\hline Own2 & $\begin{array}{l}\text { members have a mutually acceptable method to convert into money their proprietary interest in the family } \\
\text { S }\end{array}$ \\
\hline Own3 & $\begin{array}{l}\text { policy exists on the way in which equity in the family business can be transferred from one family member } \\
\text { r }\end{array}$ \\
\hline Fair1 & ior generation family members provide for the unique needs of each heir \\
\hline Fair2 & $\begin{array}{l}\text { The senior generation family members have fair wills for the active as well as the inactive family members of the } \\
\text { younger generation }\end{array}$ \\
\hline Fair3 & $\begin{array}{l}\text { ls of the senior generation family members are fair towards the younger generation family members that are } \\
\text { the family business }\end{array}$ \\
\hline Fair4 & amily $\mathrm{r}$ \\
\hline Fair5 & $\begin{array}{l}\text { The wills of the senior generation family members are fair towards the younger generation family members that are } \\
\text { inactive in (not in the service of) the family business }\end{array}$ \\
\hline Ret1 & t packages are available to the senior generation family members in the family business \\
\hline Ret2 & family members have determined their expected current and future lifestyle \\
\hline Ret3 & $\begin{array}{l}\text { Sufficient provision was made so that the senior generation family members will be financially secure after } \\
\text { retirement }\end{array}$ \\
\hline Ret4 & e senior generation family members will not be financially dependent on the family business after retirement \\
\hline Ret5 & amme of the family bu \\
\hline Ret6 & ly business has a financial system in place that ensures the financial independence of its retirees \\
\hline Ret7 & $\begin{array}{l}\text { The existing capital available to the senior generation family members will generate the income and cash flow to } \\
\text { meet their expenditure requirements for the remainder of their lifetimes }\end{array}$ \\
\hline Liq1 & The family business will be financially secure after the retirement of the senior generation family members \\
\hline Liq2 & $\begin{array}{l}\text { Sufficient capital will be available to successfully manage the family business after the retirement of the senior } \\
\text { generation family members }\end{array}$ \\
\hline Liq3 & $\begin{array}{l}\text { The financial retirement needs of the senior generation family members should not put the family business under } \\
\text { financial strain }\end{array}$ \\
\hline Liq4 & 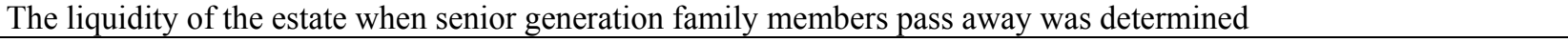 \\
\hline
\end{tabular}

The item indicating the number of the items measuring the five latent constructs, i.e. estate planning (EP), impact of estate taxes (Tax), acquiring equity ownership in the business (Own), perceived fairness of the will (Fair), retirement planning (Ret) and perceived liquidity of business after succession (Liq) 
